\title{
A Maldição do Vale Negro e a inversão das fórmulas de fazer chorar
}

Gustavo Guenzburger

\begin{abstract}
Resumo
Explorando o conceito das fórmulas afetivas de Aby Warburg, este trabalho acompanha o processo de inversão das velhas formas melodramáticas que se apresenta na montagem carioca de 1988 de A Maldição do Vale Negro, texto de Caio Fernando Abreu e Luiz Arthur Nunes. Pela perspectiva da recepção da peça, o artigo busca também situar este mecanismo, e o próprio espetáculo, no contexto do teatro carioca, que se reformulava diante de um novo cenário cultural de universalização das telenovelas e de seu estilo naturalista de atuação.
\end{abstract}

Palavras-chave: fórmulas afetivas, melodrama, mediação, teatro carioca, telenovela. 
Na província francesa de Castelfranc, entre os ciprestes e pinheiros do famigerado Vale Negro, ergue-se, imponente, a mansão da antiquíssima linhagem dos condes de Belmont. Quando a água da cascata silencia, gritos e ruídos horriveis costumam sair do interior deste castelo: é sinal de que algo de terrível está para acontecer. Esta é a Maldição do Vale Negro. Alheia a tudo isto, a meiga e órfã Rosalinda é criada sob o rígido controle de seu querido padrinho, o velho e doente Conde Maurício de Belmont, e da governanta Ágatha, tão tenebrosa quanto corcunda e maléfica. Ambos os personagens guardam um segredo que pode mudar a vida da garota. Um dia, a cascata interrompe suas águas. A catástrofe logo aparece: o jovem e impertinente Marquês D'Allençon vem exigir do velho conde que este lhe passe todas as suas propriedades, exibindo para isso uma carta de hipoteca, resultado das antigas aventuras de jogo do conde com o falecido pai do atual marquês. É a maldição que recai sobre o vale...

Por incrível que pareça, estamos vendo este folhetim sendo feito a sério por atores em um palco carioca de 1988, e entre trovoadas, ataques de orquestra e cenários pintados em telões, ainda não sabemos se devemos rir ou chorar diante das agruras deste dramalhão anacrônico. Essa dúvida está documentada na carta que o professor de literatura Ivan Proença escreveu recomendando o espetáculo aos seus alunos:

[...] observei que, só após meia hora de peça, um senhor 'ousou' rir do que se passava no palco. De pronto, vários rostos censores e irados se voltaram 'contra' aquele insensível e inoportuno cidadão. No segundo ato, porém, já não se crucificavam largos sorrisos (PROENÇA, 1988).

A peça certamente era para rir, e a partir de um certo momento era isso que a plateia fazia convulsivamente, quanto mais dilacerantes fossem os dramas e sofrimentos dos personagens. Mas o que haveria de tão engraçado naquela peça lacrimosa que cheirava a coisa velha?

A Maldição do Vale Negro é uma daquelas poucas peças de teatro que foram realmente escritas a quatro mãos. A primeira 
etapa desta criação conjunta aconteceu em 1976, quando Caio Fernando Abreu e Luiz Arthur Nunes aproveitaram um motivo romanesco que o primeiro havia criado ainda na adolescência para comporem a quarta esquete do espetáculo estudantil Sarau das 9 às 11. Comentando essa primeira escrita, Luiz Arthur não deixa dúvidas quanto à intenção cômica dos autores ao contar que "[...] foram quatro dias de gargalhadas, latinhas de cerveja e pizzas por telefone" (ABREU, 2009, p. 10). Dez anos depois, ampliaram aquele esquete para um espetáculo completo e profissional, que já recebeu uma enxurrada de críticas positivas em Porto Alegre, inclusive do respeitadíssimo crítico carioca Yan Michalski, para quem os autores "[...] mergulharam fundo na herança cultural do melodrama clássico, e escreveram um espirituoso texto que reúne, despudoradamente, vários dos mais batidos clichês e arquétipos do gênero" (MICHALSKI, 1986).

Sobre a possível dificuldade de se escrever em dupla, o diretor lembra que

Tinha sido fácil na fase do Sarau e continuou sendo na segunda versão da Maldição. Via de regra, redigíamos juntos: a frase que um inventava puxava a frase do outro. Mas podia acontecer também de um escrever uma cena e o outro retocála. Interferíamos sempre em nossas invenções sem nenhum constrangimento. Que sintonia era essa? Era como brincar juntos (ABREU, 2009, p. 10-11).

Esta brincadeira gerou não um melodrama autêntico, mas uma paródia ou pastiche do gênero, a partir da reunião de todos os seus clichês: vilões cruéis, revelações súbitas, reconhecimentos de parentes perdidos, venenos, tisanas, punhais, medalhões, ciganos, masmorras, passagens secretas, punição dos maus e recompensa dos justos.

O sucesso de crítica e público em Porto Alegre animou a produção do espetáculo no Rio de Janeiro. No programa desta temporada, o autor e diretor do espetáculo esclarece que

[...] o texto exagera e, portanto satiriza o efeito fácil, a falsificação da realidade, a alienação da ideologia implícita, baseada num maniqueísmo simplista e numa ilusória providência divina que, embora retardando o final, garante sempre a vitória da justiça e do bem (NUNES, 1988). 
Escondido na perfeita simbiose entre um escritor e um diretor na autoria deste texto teatral premiado, mas ainda pouco estudado, pode residir o fato de que sua sátira é mais teatral do que textual. Cada frase de efeito sugere uma postura corporal estigmatizada, cada reviravolta do enredo corresponde a um movimento cênico de impacto visual ou sonoro, cada personagem estereotipado exige do ator um conhecimento do estilo antigo de atuação, suas convenções, seus atalhos. Afinal, tudo no texto foi escrito para a cena, uma cena que quer falar de si própria, de seu passado e seu presente, ainda que para se ridicularizar, se denunciar, se pesquisar.

Na montagem a que estamos assistindo agora, em 1988, a peça recebe o Prêmio Molière de melhor autor. Mas porque será que em 1988 este amontoado de clichês, efeitos previsíveis e bombásticos, desfechos mirabolantes, causa tanta graça e é considerado justamente o melhor texto do ano?

II

Ao se dar conta de que a única forma de obter o perdão para a divida do padrinho seria entregar-se ao credor da hipoteca, a casta Rosalinda se deixa seduzir, cheia de pudores, pelo jovem e cruel marquês. Os dois iniciam um relacionamento secreto, e a jovem termina por se apaixonar pelo lúbrico mancebo. Um dia, Rosalinda descobre que está grávida. A reação do marquês é terrível: frustra qualquer esperança matrimonial da jovem, rompendo com ela e desprezando-a. A resposta do padrinho, o Conde de Belmont, cuja dívida de jogo havia sido resgatada à custa da castidade da pequena, também não é melhor: expulsa a jovem do castelo, lançando-lhe as mais terríveis maldições. Rosalinda se atira sozinha pelo mundo, desprezada e abandonada. No acampamento de ciganos onde é acolhida, a pobre órfã descobrirá seu passado e os segredos que envolvem o Vale Negro.

A virtude perdida da mocinha já era um drama estranho à realidade social da plateia do final do século XX. Aqui o público começa a se distanciar e achar graça. Apesar de toda a estética tonitruante, da linguagem rebuscada, da segunda pessoa, especialmente no plural, tudo na peça até então vinha 
sendo reconhecível como problema aceitável para a cultura daquele momento - a hipoteca, a governanta vilã - ainda que caricata e lúbrica -, o galã sem coração, a órfã ingênua. Mas em 1988 a questão da virgindade já não estava mais colocada naqueles termos catastróficos. E quanto mais sofria a personagem Rosalinda, quanto mais a atriz Angela Valério se atirava na realidade - teatral - da angústia de menina moça que "se perdeu", mais risos tirava da plateia. Parecia que agora o público entendia de vez a proposta do espetáculo: quanto mais sério, mais engraçado.

Ainda no programa da peça, o diretor adverte que sua encenação,

[...] para ser paródia, tem que ser a 'sério'. Sem deboche. Fidelidade ao estilo: grandiloquência no falar, gesticulação exacerbada, poses, caras, bocas e figurinos de época, telões pintados, música ao fundo. Tudo isso só fica engraçado se feito pra valer. Daí, a pesquisa de uma forma teatral passada, a redescoberta de um jogo de regras preciosas e precisas. Teatro puro, artifício, ilusão, mentira, prazer (NUNES, 1988).

Yan Michalski já havia notado esta intenção em sua crítica à montagem de Porto Alegre: “E Luiz Arthur encenou esse texto com a maior seriedade e com total respeito às convenções do seu anacrônico estilo cênico. Essa seriedade e esse respeito produziram, é claro, um resultado de notável poder cômico" (MICHALSKI, 1986). A crítica carioca também foi unânime quanto ao bom resultado desta estratégia de encenação. Macksen Luiz acha que "[...] a direção desenha com estilo [...] cada cena do espetáculo, o que revela um cuidado de acabamento e um detalhamento raros de se encontrar ultimamente [...]", (LUIZ, 1988) e Armindo Blanco atenta para o potencial de pesquisa de linguagem embutido na inusitada proposta, definindo-a como "[...] uma experiência quase laboratorial, muito envolvente na relação com a plateia, graças à perfeita e disciplinada identificação dos atores com o autor/ diretor" (BLANCO, 1988).

Se em 1988 o diretor opta por encenar "a sério" um Frankenstein de velhas paixões dos séculos XVIII e XIX, e justamente por causa disto alcança grande êxito, podemos supor que era o estilo melodramático em si que tinha algo a dizer para aquela plateia. Portanto, não nos resta outra opção 
a não ser seguirmos um pouco aqui as pegadas deste estilo, para tentar compreender assim o que e como estava sendo comunicado naquela encenação.

Ivete Huppes, em seu livro Melodrama: o Gênero e sua Permanência (2000), liga a origem do melodrama à ópera italiana do século XVII, em suas variações de ópera popular e opereta, passando então à França, onde atingiu "[...] o estágio composicional que veio a conquistar o prestígio e a aceitação que lhe reconhecemos. A forma é popular desde as últimas décadas do século XVIII" (HUPPES, 2000, p. 21). Segundo o Dicionário de Teatro de Patrice Pavis (1999), na França o melodrama

[...] passa a ser um novo gênero, aquele de uma peça popular que, mostrando os bons e maus em situações apavorantes ou enternecedoras, visa comover o público com pouca preocupação com o texto, mas com grandes reforços de efeitos cênicos (PAVIS, 1999, 238-9).

Preferindo os efeitos visuais e os golpes de teatro em detrimento da elegância do texto ou da coerência do enredo, o gênero não só se aproxima das massas pós-revolucionárias como serve de veículo para sua semieducação quanto aos ditames morais da nova ordem burguesa estabelecida. Guilbert Pixérécourt, autor que fixou o melodrama na França, diz que ele "[...] será sempre um meio de instrução para o povo porque pelo menos este gênero está ao seu alcance" (PAVIS 1999, p. 239). Para a enorme plateia de novos espectadores egressos das camadas trabalhadoras e analfabetas, que se aburguesavam e se acostumavam com as novas formas de arte e entretenimento, o melodrama era uma diversão fácil, moralizante e sem dubiedades. As personagens, separadas em boas e más, não têm uma opção trágica possível; apenas certezas e evidências sem contradição. Ao desvalorizar os contextos, este esquematismo polarizador tendia a tratar o povo como massa. A virtude era o que a massa deveria aprender a apreciar, pois ao final da peça ela seria recompensada, e a vilania punida.

No entanto, em Dos Meios às Mediações, Jesús MartínBarbero (2003, p. 169-178) chama a atenção para o caráter de mediação do melodrama. Ao negligenciar o texto em favor do visual e do auditivo, ao traçar uma trajetória que vai desde a referência parental popular, da bastarda borralheira que se descobre princesa, até seu casamento burguês com o príncipe 
virtuoso, ao insistir enfim em anacronismos do teatro de feira, este movimento teatral não atuava apenas em mão única na educação das multidões aglomeradas para a nova vida na cidade. Martín-Barbero insiste que, paralela à propaganda da nova moral e à operação simplificadora de sua dramaturgia, a sobrevivência de expressões e valores populares no melodrama embutia um movimento oposto, de resistência das camadas populares à nova ordem burguesa.

$\mathrm{Na}$ base de todos os sofrimentos do dramalhão lacrimoso se localiza o segredo das fidelidades primordiais, que pertencem à ordem das tradições populares - o mistério da paternidade, os irmãos gêmeos e/ou que se desconhecem, a pobre que não se sabe princesa. A partir desta constatação, Martín-Barbero levanta a hipótese de que a ida dos personagens "[...] do desconhecimento ao re-conhecimento da identidade [...] seria a forma pela qual a partir do popular se compreende e se expressa a opacidade e a complexidade que revestem as novas relações sociais" (MARTÍN-BARBERO, 2003, p. 178). Junto a isto, a "retórica do excesso" visual, sonoro e emotivo contém, para o estudioso espanhol, "[...] uma vitória contra a repressão, contra uma determinada 'economia' da ordem, a da poupança e da retenção [burguesas]” (p. 178).

A operação puramente ideológica ou comercial da propaganda não seria suficiente, segundo Martín-Barbero, para explicar a persistência da forma melodramática na atualidade e nos vários meios tecnológicos posteriores a seu surgimento, fazendo-se necessário discutir as questões de suas matrizes culturais e de seu papel de mediação entre "[...] o folclore das feiras e o espetáculo popular-urbano, quer dizer, massivo" (MARTÍN-BARBERO, 2003, p. 178). A partir deste olhar de mediação, Martín-Barbero indica que o melodrama deixa de ser um antecedente de suas formas mais modernas, pois se torna um paradigma: “Do cinema ao radioteatro, uma história dos modos de narrar e da encenação da cultura de massa é, em grande parte, uma história do melodrama" (p. 178).

No Brasil, como atesta João Roberto Faria (GUINSBURG; FARIA; LIMA, 2006, p. 179), o gênero foi introduzido pela dramaturgia de autores franceses como Victor Ducange, Anicet Burgeois, Joseph Bouchardy e Adolphe Dennery, nos tempos áureos das interpretações arrebatadas de João Caetano. Ainda que o melodrama depois tenha sido alvo do 
${ }^{1}$ Rede Globo, 1985-86.

${ }^{2}$ Segundo o PNAD, $71,5 \%$ dos domicílios possuíam televisão em 1988. Fonte IBGE: $<$ http://www.abert.org. br/web/index.php/notmenu/item/18076-ibge-divulga-dados-estatisticos-de-radio-e-tv $>$. Acesso em 15/02/2015. Segundo o IBOPE, Roque Santeiro, em 198586 , obteve média de 67 pontos de audiência e 96 no último capítulo, com picos de 100 pontos. Fonte: <http:// pt.wikipedia.org/wiki/ Roque_Santeiro>. Acesso em $15 / 02 / 2015$. desprezo dos escritores cultos da comédia realista da geração do Teatro Ginásio Dramático, e objeto de chacota da indústria dos musicais dos tempos de Artur Azevedo, o moralismo, o sentimentalismo, a linguagem enfática, a gestualidade exacerbada e a dramaticidade paroxística continuaram permeando o palco do século XIX brasileiro, deixando marcas que nunca abandonariam a sensibilidade nacional.

No início do século XX, o melodrama migrou para o circoteatro, no qual permaneceu até o fim do lento desaparecimento deste gênero de teatro ambulante, ou seja, meados da década de 80. Antes foi desaparecendo gradativamente de nossos palcos italianos até sumir definitivamente em 1940 enquanto gênero acabado. Mas características melodramáticas continuaram sendo utilizadas por alguns dramaturgos brasileiros modernos, em busca dos mais variados efeitos, como é o caso explícito de Nelson Rodrigues, que abusa deliberadamente das reviravoltas surpreendentes e das narrativas folhetinescas em suas peças, quase sempre no intuito de denunciar a decadência da estrutura patriarcal da família carioca.

Apesar do estigma de arte menor e alienante, o melodrama se espalhou mundialmente e especialmente no Brasil, revelando uma extraordinária capacidade de renovação ao metamorfosear-se nos mais variados formatos narrativos - folhetim, circo-teatro, cinema mudo, cinema falado - e principalmente cantado - radioteatro, radionovela, telenovela.

Sempre que uma nova tecnologia de comunicação de massa é inventada, imediatamente uma nova forma melodramática surge para utilizar este suporte. Neste mecanismo de renovação da indústria cultural, o gosto pelo dramalhão foi deixando de diferenciar classes sociais, ao atrair para a frente dos rádios, e depois das telas brasileiras, os ricos e os pobres, letrados e analfabetos, todos igualmente ansiosos para saber se no último capítulo os bons seriam recompensados e os maus, punidos.

E aqui chegamos de volta ao nosso público de 1988, que começa a evitar o teatro com medo da violência, a ponto de na década seguinte frequentar apenas os teatros dos shopping centers. Ao mesmo tempo, a partir de Roque Santeiro ${ }^{1}$ a telenovela começa a atingir a grande maioria dos lares brasileiros ${ }^{2}$ pois, ao contrário do que previram Adorno e Horkheimer (1985), a 
atração pelo divismo da indústria cultural brasileira não fazia distinção de classe ou de formação.

Então não podemos negar esse fenômeno na recepção de A Maldição do Vale Negro de 1988-89. Na plateia estavam pessoas que lidavam com aquela realidade de uma maneira ou de outra, fosse optando por ir ao teatro para fugir à universalização do melodrama televisivo, ou ao contrário, fosse saindo de casa pelo antigo hábito de ir ao teatro ou obrigado pela namorada, mesmo que com o coração apertado por perder um dos capítulos decisivos da novela Vale Tudo.

Flávio Luiz Porto e Silva (SILVA, 2005) mostra que a permanência de características melodramáticas nas telenovelas exige delas constantes atualizações, entre elas, a da castidade feminina.

Embora o conceito de virtude, associada à virgindade e à pureza, tenha sido deixado de lado e substituído por outros valores como nobreza de sentimentos e amor verdadeiro, tais transformações - poderíamos arriscar chamá-las de "atualizações" - emprestam mais realidade às personagens e à própria trama, mesmo que esta se desenvolva num emaranhado de sendas melodramáticas, com reviravoltas e peripécias seguidas, a perseguirem um desfecho feliz para os bons e a punição para os maus. A filiação com o melodrama é total; é como se todos os elementos exigidos pelo gênero aí se explicitassem, inclusive a mensagem moralizante (SILVA, 2005, p. 51).

Se na TV a mocinha continuava nos comovendo com sua virtude modernizada em nobreza de sentimentos, como compreender em um palco de 1988 o efeito cômico provocado por uma donzela que esqueceu de se atualizar, que ao invés de lutar pela nobreza moderna de um amor verdadeiro insiste em chorar pela vergonha caduca de uma virgindade para sempre perdida?

\section{III}

Depois de muito vagar pela floresta, a pobre Rosalinda adormece junto a uma clareira, perdida, abandonada pelo padrinho e desprezada por seu amor. Mas o destino faz com que a jovem encontre o acampamento onde a astuta e forte cigana Jezebel prevê nas cartas a sorte futura, e o cego cigano Vassili toca uma linda melodia ao violino. Ao 
ouvir a voz da jovem, o cigano tem um estremecimento. Parece-lhe uma voz há muito conhecida. A capa e o medalhão que a moça traz do castelo não deixam dúvidas: Rosalinda é a filha do cego e corajoso cigano Vassili! Não há tempo a perder: os três se dirigem ao castelo dos Belmont, para tentarem encontrar Úrsula, o grande amor do cigano, e mãe de Rosalinda.

A mocinha na sarjeta, a coincidência inverossímil, o reconhecimento espetacular pelo medalhão - tudo isso nos dá em 1988 a forte sensação de uma narrativa antiga, e podemos rir com a certeza de que rimos de uma forma ingênua de narrativa. Quão engraçado nos parece agora que nossos avós se emocionassem realmente com tamanha inverossimilhança! E essa sensação nos causa até um certo conforto, pois estamos na cômoda posição de reconhecimento do caráter tosco do teatro antigo, o que automaticamente nos remete ao sentimento de progresso da arte. Ao assistirmos ao velho, todo o novo nos parece mais rebuscado, menos óbvio, mais civilizado.

Mas em determinado momento, a paródia de A Maldição do Vale Negro se torna tão engraçada para a plateia de 1988, tão familiar, que fica evidente o poder atualizante daquela sátira. Além disso, a seriedade da encenação, o jogo delicado dos atores que se esmeram em dar verdade aos clichês, transforma a peça em um laboratório de pesquisa sobre as regras, os limites e as possibilidades do teatro. Faz-se necessário, portanto, indagar sobre as possibilidades de atualização das fórmulas batidas do teatro das convenções.

Sobre o assunto das reelaborações de formas artísticas antigas, Carlinda Fragale Pate Nunez se coloca entre os muitos pesquisadores brasileiros a voltar suas atenções para as ideias do historiador de arte alemão Aby Warburg (1866-1929), que procurou pesquisar a permanência de características da antiguidade clássica pagã na cultura da civilização ocidental. Em seu Atlas Mnemosyne, Warburg (2012) pesquisou a maneira como as emoções básicas, engendradas no nascimento da civilização ocidental, são transmitidas por cadeias de características visuais através dos tempos. Essas imagens que viajam no tempo foram denominadas por ele como "pathosformeln" - ou "fórmulas afetivas". Em um de seus 
artigos, Carlinda explica que as fórmulas afetivas de Warburg são gestos arquetípicos ligados às emoções pela repetição através dos tempos e pela capacidade de condensar em imagem uma "[...] situação de caráter emocional (páthos) num cânon ao qual automaticamente remetem (formeln), já que, de sua forma irrompe o conteúdo" (NUNEZ, 2010, p. 55).

Warburg acredita no caráter pré-racional destas formas corporais que, por conservarem a função dêitica de sua origem anterior aos conceitos, expressariam instantaneamente um movimento psíquico não mediado pelo intelecto. Assim, a tradição de reaproveitamento destas formas, nos mais variados contextos, recuperaria a cada vez alguns aspectos intangíveis da subjetividade humana, através da memória corporal.

Gary A. Thomlinson afirma que, nesta corrente de transmissão emotiva descrita por Warburg, o gesto de uma figura antiga só pode reaparecer em outra obra de arte se estiver trasmudado no seu oposto. Para este musicologista, o conceito de Warburg de uma forma pictórica de páthos ganha força e persiste até hoje

[...] porque em suas preocupações inaugurou um século em que o irracional que o Ocidente já imaginava ter superado veio a parecer obstinadamente persistente; porque, começando por Nietzche ao longo de uma estrada seguida também por Freud, Adorno e outros, ele mostrou que a modernidade não era um bom escudo contra os terrores da não-razão, fosse pessoal ou social (TOMLINSON, 2004, p. 195).

Nesse sentido, podemos pensar as fórmulas emotivas como frestas no edifício do discurso racional do Ocidente. Rachaduras que se invertem e se reacomodam sempre de maneria a permanecerem abertas, para que delas continue a jorrar o emocional, o irracional, o afetivo - seja na mais elaborada e erudita forma de arte renascentista, seja na arte surrealista, ou ainda na arte de propaganda nazista ou no mais mercadológico produto da indústria cultural.

O historiador francês Philippe Allain Michaud, em Aby Warburg e a Imagem em Movimento (2013), comenta sobre como o método iconográfico utilizado por Warburg descobre antigos temas mitológicos da antiguidade retrabalhados nas pinturas renascentistas. O estudioso alemão não os enxergou como uma reafirmação de doutrinas clássicas, mas enquanto um mote que 
a arte do renascimento aproveitou para pesquisar a própria figuratividade: "Então, como propôs Warburg, percebemos que o argumento mitográfico era, para o pintor do renascimento, apenas um pretexto para enunciar os movimentos de que uma figura é capaz" (MICHAUD, 2013, p. 84). No mesmo livro, o autor também cita o uso de formas arcaicas dos espetáculos populares - circenses - nos primórdios do cinema, período em que essa arte ainda buscava uma linguagem para si. Pois como afirma Didi-Huberman, "[...] toda transformação, segundo Warburg - toda propensão para o futuro, toda descoberta intensa, toda novidade radical -, passa pela revisitação de 'palavras originárias'"' (DIDI-HUBERMAN, 2013, p. 216).

Mas Didi-Huberman também aponta para o fato de que estas origens, na antropologia warburguiana, não podem ser consideradas como "fontes puras" daquilo que irão se tornar depois. As tais "palavras originárias" só têm existência enquanto fantasmas, sobrevivências mascaradas, contaminadas ou mesmo invertidas. Por isso, o projeto final e inacabado de Warburg, seu Atlas Mnemosyne, consistia de painéis anacrônicos de fotografias de obras de todos os tempos, sem uma ordem racional, onde o pesquisador podia comparar a figura de uma bacante pagã com a de sua reaparição como anjo da anunciação renascentista, ou com as características de um assexuado anjo barroco. Se vivo fosse Warburg, talvez esta mesma placa contivesse hoje o rosto ambíguo e angelical de Marilyn Monroe como sex symbol em um cartaz de Hollywood e depois como crítica à indústria cultural em um quadro seriado de Andy Warhol. Por um princípio que Warburg aproveitou de suas leituras de Darwin, ele acreditou que o mesmo mecanismo de "lembrança inconsciente" que atualiza e pereniza o caráter primitivo dos movimentos expressivos, era aquele que, através de processos de associação - deslocamento, estranheza - e antítese, transformava-os em "fórmulas manipuláveis em todos os campos da cultura" (DIDI-HUBERMAN, 2013, p. 204).

Se fizermos, à maneira de Warburg, uma tabela juntando posturas, movimentos e expressões faciais de galãs dos musicais melosos de Hollywood, poderemos encontrar cadeias de correspondências em fotos e pinturas de artistas da cena de toda a nossa história, seja no teatro e na ópera do século XIX, na ópera italiana do século XVII, indo até as estátuas renascentistas e greco-romanas. Acharemos as fórmulas 
emotivas que acabaram moldando os clichês corporais norteadores do teatro e dos atores de todos os séculos.

O pesquisador norte-americano Joseph Roach (1993) comprova que só no século XX o pensamento científico foi capaz de elaborar uma técnica racional e analítica para a atuação, com a reelaboração que Stanislavski fez do Paradoxo de Diderot, sob a luz da psicologia reflexiva de Pavlov. Roach mostra que, antes disso, a realidade do teatro romântico do século XIX era dividida em duas formas distintas de se enxergar o ofício do ator. Poetas, críticos e teóricos românticos acreditavam no vitalismo, na espontaneidade, na organicidade como chave para a interpretação dos personagens bombásticos e paroxísticos da época, enquanto que seus reais executores, os atores, costumavam afirmar em depoimentos que atuar já dependia de um virtuosismo técnico, controlável, premeditado, resultado de aprendizagem e treino - mesmo que tudo isso fosse calcado e retransmitido através do ofício e dos canais da tradição (ROACH, 1993, p. 165). Para o próprio ator, seu trabalho era basicamente conhecer, dominar e executar as convenções por meio das quais se podiam expressar as emoções. Mas essas não eram tarefas reconhecidas como artísticas pela ideologia romântica que preconizava a genialidade.

Roach (1993, p. 168-169) cita o exemplo do ator Edmund Kean, considerado pela crítica inglesa como o "gênio impulsivo" do palco romântico. Kean reclamava que os críticos nunca perceberam sua arte como sendo fruto de elaboração e trabalho, mas só de impulsividade ou genialidade. No entanto, este ofício, para o ator romântico virtuose, era muito parecido com o virtuosismo do cantor de ópera, que tem que treinar para adequar sua voz à estética amplificada da tradição do bel canto, das grandes orquestras e dos grandes teatros. $\mathrm{O}$ ator de dramas românticos, e mais ainda o ator dos melodramas, tinha de adaptar seu corpo e voz aos códigos corporais amplificados, consagrados pela tradição das Pathosformeln, que serviram nesta época como codificação cênica necessária para as emoções extremas do romantismo. Esta codificação era passada de geração a geração através da prática do ofício, e mais tarde em academias, principalmente na França, onde professores ensinavam e manuais ilustravam as maneiras corretas de se expressar piedade, terror, tristeza, alegria, inveja, escárnio. 
Assim, a adaptação do melodrama ao palco do Brasil no século XIX não significou simplesmente uma enxurrada de valores franceses despejados do palco para a plateia. Junto com o amor à virtude, à humildade, à justiça, à abnegação e bondade, nossa cultura do melodrama - mesmo a de dramaturgia nacional - retrabalhou e assimilou à sua maneira muitas das formas corporais exacerbadas que se forjaram durante séculos e se consagraram como códigos para expressão de sentimentos de uma civilização burguesa nascente e basicamente europeia. Com esta importação e adaptação de cânones corporais, um certo lado "irracional" da cultura europeia serviu de ponte para o contrabando de valores morais e principalmente do próprio sentimento de pertencimento da crescente burguesia nacional frente aos padrões estrangeiros.

Para o pesquisador de teatro, esta padronização em fórmulas é notável no estudo dos manuais e livros didáticos sobre teatro, até ou ainda no século XX. Em Técnica Teatral, de 1949, Otávio Rangel descreve para os iniciantes as características de cada tipo consagrado pelas convenções do teatro europeu, que o Brasil adaptou. Se pensarmos em A Maldição do Vale Negro, melodrama póstumo e artificial por ter sido criado a partir dos chavões de um gênero oficialmente superado, cada personagem se encaixa em um daqueles tipos descritos por esta ou por outra cartilha. O Conde de Belmont é o galã de centro cínico; sua irmã, depois que se recupera da sandice, toma ares de dama-galã, Rosalinda é a própria ingênua, o cigano Vassili é o galã central, e por aí vão as associações. $\mathrm{Na}$ época do teatro de melodrama, cada ator era vinculado a um tipo de personagem, cada qual, por sua vez, marcado e especializado em um determinado rol de possibilidades corporais e expressivas.

Mais do que satirizar a despretensão literária da narrativa folhetinesca ou a tonitruância do teatro de melodrama, nossa $A$ Maldição do Vale Negro tem como tema central justamente estas formas consagradas de representação corporal das emoções. Entretanto, para além da sensação histórica do progresso da arte, a saturação e o anacronismo das velhas e batidas fórmulas introduzem uma dialética inexistente - como vimos anteriormente - no modelo melodramático original. Surge um signo novo que inclui o sentido lacrimoso convencional, contido no afeto irracional e fantasmático de origem, mas que 
${ }^{1}$ Arquivo pessoal de Almir Telles, que interpretou de maneira inesquecível o maléfico Conde Maurício de Belmont. Agradeço a ele pelo empréstimo da fita e por ter me formado como artista de teatro. Ovídeo é complementado aqui pela pesquisa de outras fontes e pela minha própria lembrança como espectador. Algumas cenas deste vídeo estão em: <https://youtu.be/ QQ5TVis48mI>. Acesso em 29/08/2016.

${ }^{4}$ Por terem sido todas retiradas da gravação em vídeo, as falas não estão acompanhadas desta referência, o que seria repetitivo e tornaria a leitura truncada. carrega também seu duplo invertido, aquele que resulta no riso pelo distanciamento/deslocamento e pelo descabido/antítese, segundo Warburg. O jogo do espetáculo de 1988 que estamos analisando é o de trafegar com equilíbrio e verdade cênica entre estas duas vias aparentemente opostas.

\section{IV}

Ao chegar no castelo, os ciganos pressionam a maléfica governanta Ágatha a revelar o paradeiro de Úrsula. Só ai é que Rosalinda descobre que os gritos que ela ouvira por toda a vida, e que vinham das masmorras do castelo, eram os gritos de sua aprisionada e enlouquecida mãe, que ela julgara morta. Ela então compreende a vileza de seu amado padrinho, que na verdade era seu tio, e que tivera a coragem de manter cativa a própria irmã durante 19 anos. Mas há uma esperança: ao encontrar a família reunida, Úrsula, a muito custo, retorna lentamente das profundezas do delírio em que estivera desde que fora separada dos seus e trancafiada na escuridão, para retomar a memória e a razão. Agora vão todos tirar satisfação com Maurício, o conde de Belmont.

A louca Úrsula voltando à razão depois de 19 anos trancafiada é um escracho para a plateia, cujas gargalhadas nessa hora chegam a encobrir o áudio da gravação em vídeo ${ }^{3}$ do espetáculo (A MALDIÇÃO..., 1988) - fonte principal para a confecção desta análise. A inverossimilhança do absurdo levado a sério é ampliada na cena 12 , através de um requintado jogo cênico e dramatúrgico de adiamento da ação: cinco vezes a pobre mulher e mãe começa a reconhecer o antigo amor e assim a recuperar a memória, e cinco vezes desiste, voltando a recitar loucuras: "[...] as corsas de pés quebrados não podem correr. Apenas rastejam. Como os besouros caídos de costas... que não se levantam nunca mais." ${ }^{\prime 4}$ Outra hora ela parece puxar alguma lembrança do fundo do baú: "Tanto tempo. Tudo faz tanto, tanto tempo". Então assume ar profético e despeja: "Hoje é como se fora outrora. E nunca mais outra vez". A loucura da frase vazia é da personagem louca ou do gênero melodramático? Sem se importar com essa pergunta, a plateia se diverte com o tom filosofal do discurso estéril. Volta o reconhecimento: 
“Esse rosto... essa pele morena... esse corpo delgado... [detémse] Não, não! Não acredito! Vai-te daqui! És um impostor! Um sicário a mando de Maurício para me torturar ainda mais! [Em delírio] Besouro que cai de costas..." Aquela mulher esfarrapada, desgrenhada, suja, indecisa e delirante alcança o ápice da brincadeira teatral quando o contato físico a faz relembrar a sensualidade de sua antiga relação com o cigano: “O frescor de hortelã de teu hálito cálido, tuas mãos, nodosas e fortes. A carícia áspera de tua barba dura que me lanhava o colo nas noites de indizível prazer. Não, não pode ser verdade, seria bom demais." E o auge cômico da cena: "Estarei ficando louca, Virgem Santíssima?"

Gargalhamos com a louca varrida que só agora, saindo da loucura, começa a desconfiar da mesma. Mas estaremos rindo da ingenuidade dos dramas de nossos bisavôs ou, sem saber, rimos de nós mesmos? Nós, que antes da ceia de véspera do Natal de 1988 chegamos a picos de 92 pontos de audiência para ver alguém matar Odete Roitmann? ${ }^{5}$ Talvez a obscenidade do melodramático explícito no palco provoque em nós um riso desmedido, não o enciclopédico, mas o riso de quem está sendo exposto, na cena, pelo desvendamento dos mecanismos de nosso próprio sentimentalismo barato.

O metamelodrama de Caio Fernando Abreu e Luiz Arthur Nunes é encenado seriamente no final da década de 80 por atrizes e atores maduros - mas com pouca participação em novelas da TV Globo -, de uma geração formada no extremo profissionalismo do sistema de artistas-empresários que formava o moderno teatro carioca. Este sistema se sustentava pela bilheteria de encenações marcadas pelo realismo e se calcava parcialmente na grande difusão resultante de sua simbiose com o star-system da televisão. (GUENZBURGER,

${ }^{5}$ Novela Vale Tudo. É provável que o leitor também tenha atrasado sua ceia de natal naquele ano. Fonte: <https:// ibopetvaudiencia.wordpress.com/2012/01/28/ novela-em-destaque-5a-temp-o-sucesso-vale-tudo/>. Ver também: <http://pt.wikipedia. org/wiki/Vale Tudo Audi.C3.AAncia>. Acesso em $15 / 02 / 2015$. 2015a; 2015b). Para além da formação e da prática como contratados junto à primeira geração de estrelas modernas de teatro e TV, os artistas desta montagem de A Maldição do Vale Negro chegaram a dividir o palco com colegas da escola antiga anterior, e por isso mesmo se instruíram também na tradição das convenções, tornando-se habilitados a executar, com verdade e técnica, as formas mais codificadas e amplificadas de interpretação. $\mathrm{O}$ impressionante resultado artístico desta confluência gerou um mecanismo cênico que pôs à luz uma 
faceta do gosto e do consumo que é pouco assumida pela sociedade brasileira: a da sensibilidade exacerbada.

Neste aspecto, a peça se chocava com o panorama cultural carioca do final da década de 80, que marcou a conquista do monopólio da dramaturgia televisual pela Rede Globo, e a consagração da novela "global" como parâmetro universal da mimese brasileira: um melodrama que se dissimula e se dilui pela ilusão do real. Tomadas externas, tecnologia visual, opção pela padronização do cotidiano em roteiros, figurinos, diálogos, cenários - tudo é voltado de certa forma a dar uma sensação de realidade que possa amenizar ou mesmo esconder o caráter banal das emoções fáceis que estão sendo industrialmente produzidas ali.

Dentro desta lógica amenizante e dissimuladora, a característica mais distintiva da teledramaturgia brasileira do padrão Globo, que ao final dos anos 80 já estava em estágio avançado, é justamente a tentativa de ocultação total das Pathosformeln - "fórmulas afetivas" - no campo da atuação. $\mathrm{O}$ ator que se empregou nas indústrias Globo para atuar em novelas e minisséries foi sendo incentivado cada vez mais a reprimir os movimentos e posturas ancestrais de expressão dos sentimentos. E em seguida, excetuando-se a linha de humor e de show, os artistas da nova geração, aqueles que não precisaram mais passar pelo palco para chegar às telas, já aprenderam o ofício desta forma. Pois a estrutura ali montada para escolher, capacitar e dirigir os intérpretes, resulta em uma praxe que estimula os atores a interpretarem a si mesmos, com gestos contidos, sobrancelhas e feições paralisadas, vozes sussurradas e toda uma nova codificação minimalista que é criada para dar a impressão de "pedaço de vida" às mais escabrosas e folhetinescas tramas.

Esta lógica industrial de simulacro se autoalimenta dos valores e signos que ela mesma produz. Exige e assim universaliza uma espécie padronizada de atuação "naturalista" que, ao mesmo tempo que dissemina, também dissimula a operação simplificadora inerente ao sentimentalismo barato incrustrado na narrativa industrial novelesca. Tal padrão de simulação e dissimulação acaba aumentando seu alcance a ponto de se tornar uma estética universal brasileira. $\mathrm{O}$ pensador francês Jean Baudrillard (1991) diria à época que este seria o novo mundo em que vivíamos, um mundo irreferencial, 
onde um simulacro passa a ser a base para a construção de outro, e assim por diante. Vista por este ângulo, poderíamos dizer que a forte indústria audiovisual brasileira começaria a ditar, através de sua produção, o que deveria ser considerado verdadeiro, fosse para si mesma, em termos de atuação para os artistas, fosse em termos de modus vivendi para o cidadão consumidor comum.

Por outro lado, é preciso lembrar também que, no já citado livro Dos Meios às Mediações, Jesús Martín-Barbero se apoia em autores de campos diferentes como Walter Benjamin, Richard Hoggart e Raymond Williams para problematizar noções correntes e simplificadoras sobre os meios tecnológicos de comunicação na América Latina. Segundo o prefácio de Néstor García-Canclini, Martín-Barbero procura se afastar das visões dos primeiros investigadores das indústrias culturais que, ao tentarem descobrir as formas de manipulação das audiências, concluíam que o rádio, o cinema e a televisão simplesmente "[...] substituíam as tradições, as crenças e solidariedades históricas por novas formas de controle social" (MARTÍN-BARBERO, 2003, p. 23). Tanto García-Canclini quanto Martín-Barbero defendem a tese de que não se pode pensar a cultura de elite totalmente separada da popular, e nem a modernidade separada da massificação, uma vez que estas instâncias já caminhavam misturadas muito antes da aparição dos meios tecnológicos de comunicação.

Para nós, é importante salientar que Martín-Barbero destaca na TV uma capacidade de produzir "[...] a sensação de imediatez, que é um dos traços que dão forma ao cotidiano" (MARTÍN-BARBERO, 2003, p. 307). A vontade de aproximação, de clareza e simplicidade "imediata", seria a forma de a televisão realizar, com a maior eficiência e discrição possíveis, seu papel de mediação entre as massas e a ideologia hegemônica. Esta mediação inclui, desde os tempos do melodrama, a capacidade de a indústria cultural se aproximar e captar elementos da cultura popular que ela massifica.

O sucesso da indústria televisiva brasileira dos anos 80 pode ser pensado como um dos resultados da parceria entre setores das classes dominantes e o governo militar. Mas o papel mediador que ela assume deve ser analisado levando em conta seu caráter múltiplo e complexo, em parte análogo ao do teatro do melodrama no século XVIII, que, como falamos 
${ }^{6}$ Oriundos dos Seminários de Dramaturgia do Teatro de Arena: Guarnieri, Vianinha, Lauro César Muniz, Chico de Assis e Benedito Rui Barbosa. Embora Marcelo Ridenti já discuta, em vários trabalhos, as implicações ideológicas desta migração e institucionalização profissional dos artistas e intelectuais pela via do que ele chama de "atomização reificada da sociedade do espetáculo", a relação estética das obras teatrais da esquerda com seus duplos na teledramaturgia convencional ainda está por ser estudada.

${ }^{7}$ Novelas da Rede Globo de 1980 e 1988.

${ }^{8}$ Novelas da mexicana Televisa de 1994 e 1996. anteriormente, negociava a chegada de novas camadas da população francesa para a vida e os modos burgueses.

Para a televisão brasileira, este novo papel de mediação incluiu, entre outras tarefas, a velha subeducação para as massas excluídas dos serviços de educação estatal, mas principalmente no sentido do reconhecimento de valores da classe média urbana do Sudeste, enquanto padrão de vida ideal para o brasileiro. Talvez a diferenciação estilística entre os atores brasileiros e os de outros países da América Latina, que se torna notável a partir da consolidação da novela à brasileira, resulte de uma variante ou de um aperfeiçoamento deste processo de aproximação sociocultural.

O fato é que no Brasil, desde o teatro engajado dos anos 60, a necessidade de se aproximar e retratar as classes populares nasce junto com um desejo de despojamento no campo da interpretação de personagens. Se lembrarmos que grande parte de nossa teledramaturgia foi criada pelos mesmos autores que haviam fundado este paradigma na primeira fase do Teatro de Arena ${ }^{6}$, poderemos também começar a procurar aí as raízes históricas da especificidade atorial brasileira. A tentação de se pensar em uma "diferença de temperamento" do ator nacional cai por terra quando comparamos filmes - principalmente populares - de décadas anteriores. Ankito, Oscarito, Eliana Macedo, Grande Otelo e Cyll Farney se distanciam muito pouco de Cantinflas e Pedro Infante, se compararmos com o abismo estilístico que separa a verdade sincera e elegante de Glória Pires na mocinha de Selva de Pedra ou na vilã de Vale Tudo ${ }^{7}$ e a bondade espalhafatosa e inconstante de Thalía, em Marimar e María la del Barrio ${ }^{8}$. Apesar de alcançarem índices bastante razoáveis de audiência entre as classes populares brasileiras nos anos 80 e 90, estes dramalhões latinos eram inclusive encarados e assistidos por alguns atores cariocas como se fossem programas humorísticos, de tão distantes que as interpretações codificadas e suas tramas assumidamente hiperfolhetinescas estavam de nosso já estabelecido padrão amenizado.

Esta nossa normatização estilística foi decisiva para um papel que a televisão brasileira exerceria fortemente a partir da década de 70: a inclusão de novos e acelerados hábitos de consumo no cardápio de uma sociedade que procurava e ainda procura, pela via do progresso material e do crescimento econômico, o fim do que ela considera ser seu estigma de 
atraso. A teledramaturgia "global", ao se aproximar formal e literalmente dos lares brasileiros, foi certamente uma das grandes responsáveis pelo sucesso da mídia televisiva na implantação de novos padrões de comportamento e de consumo, ligados ao estilo de vida da classe média.

Desde então, o paradigma brasileiro do melodrama "naturalizado" se estabeleceu, influenciou produções televisivas de outros países, preparou o terreno para o sucesso dos "reality shows", e finalmente passou a incidir, a partir da década de 90, sobre o trabalho atorial em todos os palcos brasileiros - principalmente os cariocas -, mesmo em muitos espetáculos ou performances de concepção pouco realista9.

Mas o Vale Negro, ao retirar no teatro a poeira bolorenta das velhas fórmulas de fazer chorar, e juntar todas elas em uma hora de espetáculo para fazer rir, pode estar deixando a nu alguns mecanismos lacrimosos e sentimentalóides que nós tanto gostamos de usufruir quanto de dissimular. Será que sentimos também alguma nostalgia pela franqueza escrachada do dramalhão dos nossos avós?

Afinal, companheiros de plateia de 1988, estamos rindo mesmo do gosto de quem?

Úrsula surpreende seu irmão Maurício, ao contar que foi salva da masmorra e da loucura por seus familiares, e que quer acabar com as maldades e a exploração dos mineiros no Vale Negro. O conde, pressionado pela presença de todos, sente-se mal, e pede à governanta Ágatha sua tisana de medicamentos. A cigana Jezebel intercepta a tisana, identifica e anuncia a todos a perfídia da cruel governanta que, ao invés de remédios, medicava arsênico para o patrão já doente. A pérfida agride o cego Vassili com uma paulada, foge é é estraçalhada fora de cena pelos cães que fazem a guarda do castelo. Moribundo, o Conde Mau-

${ }^{9}$ No último capítulo de minha Tese de Doutorado analiso esta possibilidade de oposição formal entre encenação contemporânea e atuação naturalista no teatro carioca da zona sul e centro (GUENZBURGER 2015; 2016). rício se arrepende de seus atos, e antes de morrer revela a todos que sempre amou a cigana Jezebel, pedindo-lhe um derradeiro beijo, que ela concede, proporcionando-lhe uma morte feliz. Mas Jezebel antes disso confessa que seu coração sempre fora de Vassili. Este por sua vez, acorda da pancada que recebeu, para descobrir que recuperou 
a visão, e assim pode conceder a mão de sua filha Rosalinda em casamento ao também arrependido Marquês D'Allençon. Acabaram os sofrimentos e a exploração no Vale Negro, e todos podem viver felizes para sempre.

A trama do Vale Negro gira em torno de banimentos e expulsões femininas. Úrsula foi punida e trancafiada por defender uma causa nobre, a dos mineiros explorados por seu irmão, o tirânico Conde de Belmont. O conde, por sua vez, depois de encarcerar a irmã por 19 anos, ainda expulsa a sobrinha, por uma causa que, como já vimos, parece arcaica em 1988, a da quebra do decoro sexual feminino.

Assim como em 88 é risível o drama da mocinha honesta que entrega - até com alguma rapidez - sua virgindade, e engravida ao tentar salvar o tio, sendo por este incompreendida e castigada, o banimento anterior de sua mãe - a verdadeira "maldição" -, velado no início da trama, também está prenhe de signos invertidos, embora mais sutis e contextuais.

As duas punições femininas, que seriam o mote dramático do suposto melodrama, são o vértice cômico do metamelodrama. Didi-Huberman chama a atenção para a adaptação que Warburg fez da antítese, enquanto terceiro "princípio geral da expressão", conforme havia sido estudado por Charles Darwin em 1872 (DARWIN, 2000). Para isso, o professor francês explica uma ligação que Warburg enxergou entre intensidade afetiva e inversão de sentido:

Adaptado à Pathosformel, o princípio da antítese manifestase como processo que Warburg chamou de 'inversão de sentido'.[...] Em suma, a fórmula de pathos tem de paradoxal - e de comum com uma formação do inconsciente no sentido freudiano do termo - o fato de que sua vocação para intensificar o afeto na forma caminha de mãos dadas com uma espécie de insensibilidade à contradição: sempre lhe é facultado deixar uma significação pela significação antitética (DIDI-HUBERMAN, 2013, p. 209).

Vista por outro ângulo, esta inversão também pode se dar por uma falha de sentido na narrativa dramatúrgica hiperarcaica que, deslocada em sua forma do contexto contemporâneo, provoca um vazio textual só preenchível pela cena. Este movimento de troca entre linguagens é identificado 
na teoria teatral contemporânea justamente como a teatralidade do texto (SARRAZAC, 2012, p. 181-2). A teatralidade, no caso, é a falta de teatro na obra escrita.

No caso da anacrônica virgindade da mocinha, a falha de sentido do texto por sua desatualização no contexto sociocultural de recepção é evidente, e esta falta é "suprida" no palco, justamente por uma profusão de fórmulas de páthos invertidas de seu sentido original melodramático, em um show de virtuosismo cênico da atriz Angela Valério, que desfila o repertório de chavões visuais e sonoros da mocinha enganada e arrependida. Este sofrimento todo, comparado à rapidez com que ela tinha decidido se entregar na cena anterior, evidencia para o público moderno o jogo de rupturas abruptas da dramaturgia folhetinesca, atualizando, ao inverter no palco, o sentido do texto. O infortúnio em cena passa a ser exclusivamente jogo de cena, divertimento.

Já no caso do encarceramento da mãe de Rosalinda, que a plateia só vai descobrindo através das sucessivas revelações da trama e das sandices que a personagem fala desde o início, a "falta" sarrazaquiana ou a "antítese" darwiniana/ warburguiana se dá na forma com que se liga um conteúdo político descontextualizado à própria loucura, textual e corporalmente exacerbada. Entre os seus delírios de "besouros que caem de costas" e "corsas de pés quebrados" - metáforas óbvias de sua própria situação de estagnação - a personagem mistura uma listagem de clichês de discurso político libertário, em defesa das classes pobres. Na cena 6, a condessa louca - interpretada com brilhantismo e seriedade por Maria Esmeralda - confabula com uma boneca que ela julga ser sua filha perdida, falando sobre o conde, que dorme:

Vês, filhinha? É assim que são os poderosos. Desalmados, impiedosos. Dormem profundamente [...] Alheios à desventura dos oprimidos camponeses que labutam no fundo lamacento das minas para cobrir de ouro seu medonho latifúndio.

À medida que a loucura cresce, o discurso político da condessa esfarrapada vai se radicalizando:

Companheiros, uni-vos! Uni-vos para destroçar o maligno! [Segura Maurício e o sacode violentamente, até que ele 
acorde] Este, que se traveste de benfeitor dos pobres e oprimidos! Uni-vos como lobos famintos de justiça para destroçá-lo em pedaços sangrentos!

Durante as revelações espetaculares e a recuperação da memória, ficamos sabendo que Úrsula havia sido banida justamente por conta de sua afinidade com a causa dos mineiros oprimidos por seu irmão, afinidade esta que a fez sair do castelo para conhecer e se apaixonar pelo cigano Vassili.

Lembrando que estamos assistindo a este espetáculo em pleno desmoronar do bloco soviético, em meio a uma descrença geral nas ideologias de esquerda, e a um ano da queda do muro de Berlim, parece significativo que o discurso social e político apareça na peça não só como mais um chavão, mas um chavão na boca da personagem louca varrida. Além disso, a recuperação abrupta da memória e da razão só aumentam a inverossimilhança da personagem que, depois de "punidos os culpados" e "terminados os infortúnios daquelas almas abnegadas", dispara uma promessa digna de algum presidente brasileiro dos anos 80: "Amanhã mesmo congelarei todos os preços, e triplicarei o salário dos mineiros".

A parte do congelamento não está no texto (ABREU, 2009), apenas no vídeo do espetáculo, e é provavelmente uma alusão de última hora ao então recém-fracassado Plano Cruzado, de José Sarney. O sentimento brasileiro de descrença na política e nos políticos se alimentou dos personagens corruptos e do fenômeno de audiência da novela televisiva Vale Tudo, e resultaria, no ano seguinte ao do espetáculo e da novela, em uma campanha midiática que culminaria na eleição do "caçador de marajás", Fernando Collor de Mello" ${ }^{10}$. Collor renunciaria três anos depois, no final de um processo de impeachment, como resultado de outra campanha, desta vez não só midiática - dos mesmos veículos que o ajudaram

${ }_{10}$ Ver depoimento de Armando Nogueira no documentário Beyond Citizen Kane, produzido pela BBC de Londres e até hoje proibido no Brasil. Na internet, o filme está disponível, entre outros links, em: <https://www.youtube. com/watch?v=77TKL Q1op34>. Acesso em 29/08/2016. a se eleger, entre eles as Organizações Globo -, mas também dos movimentos sociais e especialmente o estudantil, dos chamados "cara-pintadas". Esta descrença nacional nos políticos se alia ao sentimento mundial que fez pensadores da época como Jean-François Lyotard (1979) chegarem a decretar o fim das metanarrativas de progresso tais como o marxismo, o estruturalismo e a ciência positivista, ou o já citado Jean Baudrillard (1991) apostar em um mundo desprovido de 
11 Tive a oportunidade de assistir a outra montagem deste mesmo texto, dirigida em 2005 também por Luiz Arthur Nunes, com uma produção bem mais confortável, graças ao patrocínio via Lei Rouanet. O elenco, competente e de peso, incluía nomes importantes e emergentes da segunda e terceira geração de atores da simbiose teatro-televisão, como Marcos Breda, Camila Pitanga, Stella Freitas e Bruno Garcia. No entanto, a meu ver, e talvez por conta da diferença geracional e de formação dos artistas, este espetáculo não alcançou o mesmo resultado daquele que é analisado aqui, tanto em termos de compreensão quanto de execução da proposta de se levar a sério o paroxismo melodramático, para dele extrair o cômico. realidade, onde os signos se alimentariam de seus próprios significantes, já que a realidade não existiria mais.

Portanto a representação ridícula do discurso político aponta para uma afinidade do espetáculo com o sentimento de pós-modernidade. Ao colocar um certo ideário convencional de esquerda no mesmo patamar melodramático de uma narrativa em que o bem fatalmente vence o mal, o dispositivo de inversão formal do espetáculo pretende expor ao riso da plateia todo tipo de salvacionismo político. Se a expulsão de Rosalinda virava uma piada através da saturação de formas corporais clássicas que reforçavam o anacronismo da questão da castidade feminina, o infortúnio de Úrsula vai ficando engraçado pela inverossimilhança do discurso marxista na boca de uma condessa ricaça e enfurecida, que trai sua classe e se joga no chão bradando contra os poderosos. São recursos teatrais hipertradicionais que tiram do contexto (des-)atualizado a sua falha ou sua inversão, e portanto, a sua graça. Afinal, independentemente da peça, tanto a virgindade da donzela casta quanto a revolução comunista andavam em baixa em 1988.

Apesar da unanimidade da crítica em relação ao texto, atores e direção, o Prêmio Molière concedido apenas aos autores e ao cenógrafo Alziro Azevedo não faz jus quanto ao achado da inesquecível encenação de Luiz Arthur Nunes. Seu maior mérito foi ter conseguido coreografar estes elementos, e mais a iluminação de Aurélio de Simone e o figurino do mesmo Alziro Azevedo, em função das impressionantes atuações de seus intérpretes. Quanto a estas, individualmente também ainda não se deu o devido valor à inteligência e energia de Almir Telles, à entrega de Angela Valério, ao timing de Ivo Fernandes, à ludicidade de Maria Esmeralda, ao rigor coreográfico de Nara Keiserman, à comicidade seríssima de Regina Rodrigues e à ousadia de Shimon Nahmias. Tecnicamente capacitados pela maturidade e pela prática profissional que o emprego com carteira assinada no mercado de estrelato lhes havia possibilitado desde décadas anteriores, esses artistas eram tão desconhecidos do grande público da TV quanto eram parte inseparável do incrível alcance artístico da peça. ${ }^{11}$

Esta produção de A Maldição do Vale Negro foi elogiada e aplaudida por boa parte da classe teatral carioca e também 
de outros estados, mas talvez se tenha pouca consciência de sua importância histórica em termos estéticos: tomou parte e também lançou algumas tendências para a década de 90 de reaproveitamento de códigos teatrais antigos, que iriam ajudar a moldar uma parcela do teatro que se produz no Brasil até hoje. O sucesso de bilheteria e de comunicabilidade que O Mistério de Irma Vap (1986) havia conseguido pela via do nonsense besteirol, a peça de Caio Fernando Abreu e Luiz Arthur Nunes alcançou em profundidade poética pela via da pesquisa de linguagem, inserindo definitivamente o melodrama no instrumental brasileiro da investigação sobre a teatralidade. Vem Buscar-me que Ainda Sou Teu (1990), de Carlos Alberto Sofredini e direção de Gabriel Villela - que também dirigiu neste viés Romeu e Julieta (1992) e Rua da Amargura (1994) do Grupo Galpão -, além de Melodrama (1994), de Felipe Miguez, encenada pela Cia dos Atores e dirigida por Enrique Diaz, são exemplos significativos de encenações posteriores que também seguiram esta linha.

Com a introdução de novas técnicas atoriais de teatro narrativo ou rapsódico, que na França já vinham sendo também experimentadas por Antoine Vitez desde a década anterior, o caminho do folhetim encenado sem adaptação dramatúrgica foi aberto e descoberto ali. Em 1990, Aderbal Freire-Filho inicia com A Mulher Carioca aos 22 Anos, de João de Minas, uma série de livros encenados, e o próprio Núcleo Carioca de Teatro, companhia formada a partir da montagem do Vale Negro, montaria A Vida como Ela É (1992), que iria inaugurar uma certa "redescoberta" de Nelson Rodrigues pelos palcos cariocas dos anos 90, através da encenação de suas crônicas folhetinescas.

Portanto, A Maldição do Vale Negro de 1988 participou e influiu fortemente no momento de criação de toda uma linhagem teatralista da cena carioca que, a partir de formas tradicionais, passou a utilizar o humor, o superdramático, o circense, o rapsódico, ou o brega, enquanto instrumentos de pesquisa cênica. Ao buscar novas formas partindo de formas antigas, este teatro tentava se aproximar do público para junto a ele procurar por novos meios de sustento, novos sentidos e novas justificativas artísticas para sua própria existência, em tempos de descrença política, diminuição de bilheterias e universalização midiática.

Mas algumas destas montagens citadas acima já fazem parte da geração seguinte de grupos e espetáculos que iriam 
fazer a transição, no Rio de Janeiro, para o teatro sustentado pelo governo, direta ou indiretamente.

\section{REFERÊNCIAS}

ABREU, C. F. Teatro completo. Rio de Janeiro, RJ: Agir, 2009.

ADORNO, T. W.; HORKHEIMER, M. Dialética do esclarecimento: fragmentos filosóficos. Rio de Janeiro: J. Zahar, 1985.

A MALDIÇÃO do Vale Negro. Direção de Luiz Arthur Nunes. Com Almir Telles, Angela Valério, Ivo Fernandes, Maria Esmeralda, Nara Keiserman, Regina Rodrigues e Shimon Nahmias. Rio de Janeiro: s. i., 1988. 1 DVD (90 min): son., col. Arquivo pessoal de Almir Telles.

BAUDRILLARD, J. Simulacros e simulações. Lisboa: Relógio D'água, 1991.

BLANCO, A. A armadilha do lixo cultural. O Dia, Rio de Janeiro, 1 set. 1988.

DARWIN, C. A expressão das emoções nos homens e nos animais. São Paulo: Cia das Letras, 2000.

DIDI-HUBERMAN, G. A Imagem Sobrevivente. Rio de Janeiro: Contraponto, 2013.

GUENZBURGER, G. Rio, cenas decisivas: teatro entre televisão, patrocínio e política. 2015. 228 f. Tese (Doutorado em Literatura Comparada) - Instituto de Letras, Universidade do Estado do Rio de Janeiro, Rio de Janeiro, 2015a.

Fernanda Montenegro em O mambembe: o quelque chose da diva moderna. Sala Preta, Brasil, v. 15, n. 1, p. 135-155, jul. 2015b. ISSN 2238-3867. Disponível em: <http://revistas.usp. br/salapreta/article/view/96070>. Acesso em: 25 ago. 2016. doi: http://dx.doi.org/10.11606/issn.2238-3867.v15i1p135-155.

. Um novo espírito teatral carioca: entre televisão, patrocínio e política. Sala Preta, Brasil, v. 16, n. 1, p. 161-178, jul. 2016. ISSN 2238-3867. Disponível em: <http://revistas.usp.br/ salapreta/article/view/102165>. Acesso em: 16 ago. 2016. doi: http://dx.doi.org/10.11606/issn.2238-3867.v16i1p161-178. 
GUINSBURG, J.; FARIA, J. R.; LIMA, M. A. de. (orgs) Dicionário do Teatro Brasileiro. São Paulo: Perspectiva: SESC São Paulo, 2006.

HUPPES, I. Melodrama: o gênero e sua permanência. São Paulo: Ateliê Editorial, 2000.

LUIZ, M. Brincar de melodrama. Jornal do Brasil, Rio de Janeiro, 9/9/1988. Caderno B, p. 6.

LYOTARD, J. -F. A condição pós-moderna. Rio de Janeiro: José Olympio, 1979.

MARTÍN-BARBERO, J. Dos meios às mediações: comunicação, cultura e hegemonia. Rio de Janeiro: UFRJ, 1997.

MICHALSKI, Y. $1^{\circ}$ Encontro Renner de Teatro. Rio de Janeiro, Boletim Informativo do Inacen, ano II, no 5, p. 9, 1986.

MICHAUD, P. A. Aby Warburg e a imagem em movimento. Rio de Janeiro: Contraponto, 2013.

NUNES, L. A. A Maldição do Vale Negro. Texto do programa da peça. 1988.

NUNEZ, C. F. P. De onde menos se espera, daí é que vem: o silêncio como fórmula de páthos das "musas pensantes". Revista Trama Interdisciplinar, v. 1, p. 51-63, 2010.

PAVIS, P. Dicionário de Teatro. São Paulo: Perspectiva, 1999.

PROENÇA, I. C. Carta a Almir Telles. 11/10/1988. Acervo pessoal de Almir Telles.

RANGEL, O. Técnica Teatral. Rio de Janeiro: Artes Gráfica Inco Ltda., 1949.

$\mathrm{ROACH}, \mathrm{J}$. R. The player's passion: studies in the science of acting. Ann Arbor: University of Michigan Press, 1993.

SARRAZAC, J.-P. Léxico do drama moderno e contemporâneo. Sao Paulo: Cosac Naify, 2012.

SILVA, F. L. P. e. Melodrama, folhetim e telenovela: anotações para um estudo comparativo. FACOM - Revista da Faculdade de Comunicação da FAAP, São Paulo n ${ }^{\circ} 15,2^{\circ}$ semestre de 2005. Disponível em: <http://www.faap.br/revista faap/revista facom/facom 15/ flavio porto.pdf $>$. Acesso em 29/08/2016. 
TOMLINSON, G. Five pictures of pathos. In: PASTER, G. K.; ROWE, K.; FLOYD-WILSON, M. (Ed.). Reading the early modern passions. Essays in the cultural history of emotion. Philadelphia: University of Pennsylvania Press, 2004.

WARBURG, A. L'Atlas Mnémosyne. Paris: L'écarquillé, INHA, 2012.

\begin{abstract}
The Curse of the Black Valley and the inversion of the formulas used to make audience cry

Exploring Aby Warburg's concept of affective formulas, this article follows the inversion of the old melodramatic forms which appears in the 1988 Rio de Janeiro staging of The Curse of the Black Valley", text by Caio Fernando Abreu and Luiz Arthur Nunes. Focused on the play's reception, this essay also seeks to situate this mechanism, and the play itself, in the Rio context of a theater reframed within a new cultural setting of universalization of soap operas and its naturalist style of acting.
\end{abstract}

Keywords: affective formulas, mediation, melodrama, theater in Rio de Janeiro, soap opera. 